\title{
Working
}

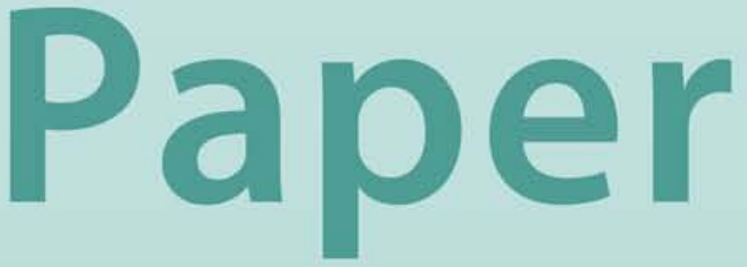




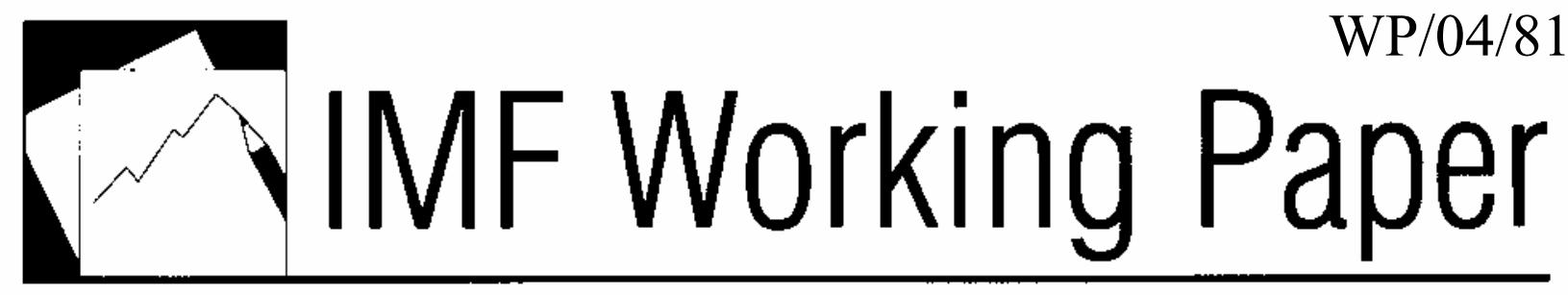

\section{The WTO and the Poorest Countries: The Stark Reality}

Aaditya Mattoo and Arvind Subramanian 


\title{
IMF Working Paper
}

Research Department

\section{The WTO and the Poorest Countries: The Stark Reality}

\author{
Prepared by Aaditya Mattoo and Arvind Subramanian ${ }^{1}$
}

May 2004

\begin{abstract}
This Working Paper should not be reported as representing the views of the IMF. The views expressed in this Working Paper are those of the author(s) and do not necessarily represent those of the IMF or IMF policy. Working Papers describe research in progress by the author(s) and are published to elicit comments and to further debate.
\end{abstract}

Small and poor countries pose a challenge for the World Trade Organization (WTO). These countries have acquired a significant say in WTO decision-making. However, they have limited ability to engage in the reciprocity game that is at the heart of the WTO, and have limited interests in the broader liberalization agenda because of their preferential access to industrial country markets. Accommodating the interests of the small and poor countries is desirable in itself, but would also facilitate expeditious progress in the Doha Round. The stark reality facing the system is that the desirable ways of addressing their concernsproviding them additional financial assistance and nonpreferential market access-is proving infeasible. As a result, the system is gravitating toward the less desirable option of relieving these countries of obligations, including those that might be welfare-enhancing for them.

JEL Classification Numbers: F1; F4

Keywords: Developing countries, Doha Round, preferences, single undertaking, WTO

Author’s E-Mail Address: amattoo@worldbank.org; asubramanian@imf.org

\footnotetext{
${ }^{1}$ The authors are respectively with the World Bank and the IMF. The views expressed in this paper and their own and do not necessarily reflect those of the institutions with which they are affiliated. They would like to thank Mark Allen, Nancy Birdsall, Peter Clark, Bill Cline, Kymberly Ann Eliott, Bernard Hoekman, Nurul Islam, Hans-Peter Lankes, Julia Nielson, Roger Nord, Dani Rodrik, André Sapir, Stephen Tokarick, Alan Winters, and participants at the Center for Global Development seminar for helpful comments.
} 


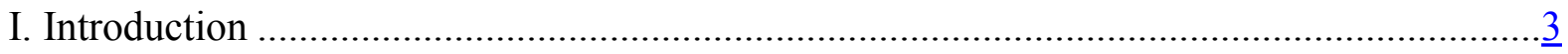

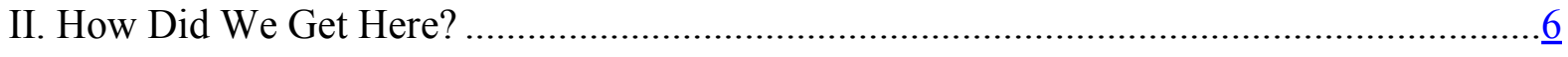

III. The Growing Influence, Its Basis, and Consequences..............................................

A. Manifestations of Influence ..................................................................... $\frac{7}{1}$

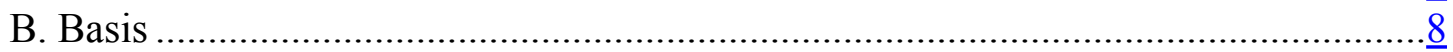

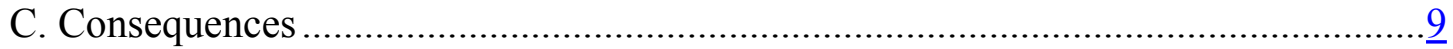

IV. Size and the Benefits from WTO membership .................................................. 10

A. Promoting Access to Foreign Markets ................................................... $\frac{10}{10}$

B. WTO to Promote and Lock in Liberalization...............................................

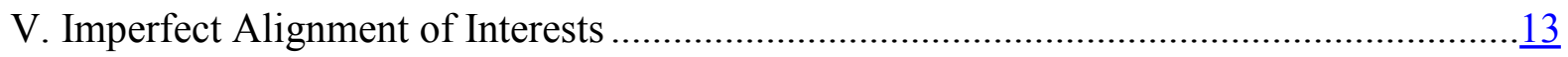

VI. Accommodating the Small and Poor Countries.................................................. 18

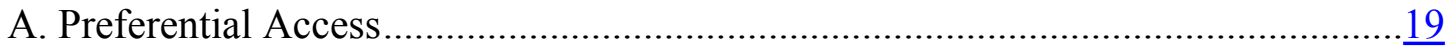

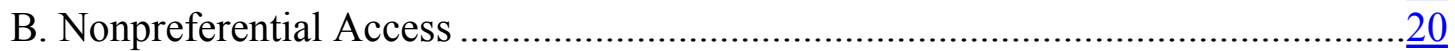

C. Limiting Costly Obligations....................................................................... $\frac{20}{21}$

D. Limiting Welfare-Enhancing Obligations...................................................

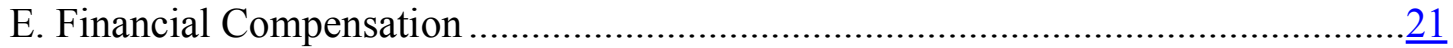

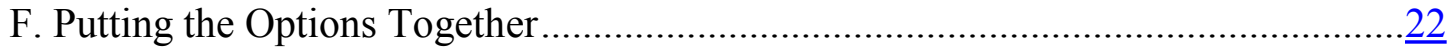

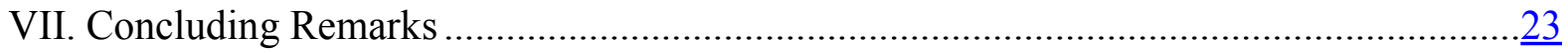

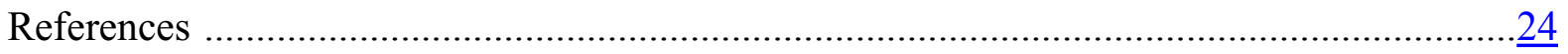

Text Tables

1. Small and Poor Countries, 2000 ..................................................................................... 4

2. Average and Bound Tariff Rates for Small and Poor WTO Members.............................12

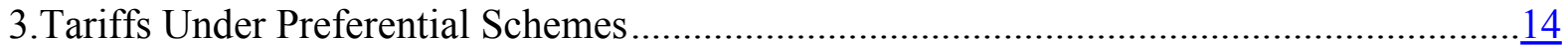

4. Net Food Imports of Small and Poor Countries.....................................................16 


\section{INTRODUCTION}

The World Trade Organization (WTO) faces a challenge relating to a group of countries that are small and poor, which account for a large and growing share of the WTO's membership (Table 1). ${ }^{2}$ First, ever since the Uruguay Round, small and poor countries have acquired significant influence in the system. The Single Undertaking of the WTO confers on these countries an important say on the advancement of multilateral liberalization. This fact sits awkwardly with two characteristics of the small and poor countries.

First, because of being small these countries do not have much to offer trading partners by way of market access concessions. This limits the extent to which they can seriously engage in, and reap benefits from, the reciprocal bargaining that is central to the operation of the WTO. ${ }^{3}$

Second, the interests of these countries are only imperfectly aligned with the broader liberalization agenda of the multilateral trading system. Since they have preferential access to the markets of the industrial countries, further multilateral liberalization would in certain areas erode rather than enhance their access to these markets. In addition, they would probably reap few benefits and incur substantial costs from the broadening of the WTO to include new areas.

Accommodating the interests of the small and poor countries is desirable in itself, but is also necessary to ensure smooth and expeditious progress in the Doha Round, especially in an intellectual and political climate that is so geared to ensuring a fair outcome for these countries. How is this to be achieved?

Conceptually, the world trading system faces a classic conflict between efficiency and distribution. Further Most Favored Nation (MFN) liberalization would lead to a more efficient allocation of global resources, but have an adverse distributional effect on those who have preferential access to markets today. The additional twist is that those who would lose (the small and poor countries) have a say in the creation of more efficient arrangements. Their say is clearly desirable from an egalitarian perspective, and the conceptual solution is

\footnotetext{
${ }^{2}$ Our list comprises countries that are both small and poor. Countries are considered small if they account for less than 0.05 percent of the world's imports of goods and services. Poor countries are those that are defined as low income by the World Bank (per capita GDP in purchasing power parity (PPP) terms of US\$4,630 or below). Of course, any line of demarcation on these two criteria will be open to challenge, but, as we explain below, the principle that the criteria should be size and income is important.

${ }^{3}$ See Hoekman and others (2003), Messerlin (2003), Finger (2002) and, especially, Wolf (2003) among others for similar analyses of the treatment of developing countries in the WTO.
} 
obvious: to devise a transfer mechanism for compensating those who would lose. The difficulty, however, lies in giving practical shape to this solution.

Table 1. Small and Poor Countries, 2000

\begin{tabular}{|c|c|c|c|c|c|}
\hline \multirow[t]{2}{*}{ Country } & \multicolumn{2}{|c|}{ Imports of goods and services } & \multirow{2}{*}{$\begin{array}{l}\text { Per Capita } \\
\text { GDP (PPP) }\end{array}$} & \multirow{2}{*}{$\begin{array}{l}\text { WTO } \\
\text { member }\end{array}$} & \multirow[t]{2}{*}{ Category $1 /$} \\
\hline & (in \$ bn.) & (share of world) & & & \\
\hline São Tomé \& Príncipe & 0.04 & 0.00 & & No; observer & African; LLDC \\
\hline Comoros & 0.06 & 0.00 & 1890 & No; observer & African; LLDC \\
\hline Guinea-Bissau & 0.13 & 0.00 & 960 & Yes & African; LLDC \\
\hline Palau & 0.13 & 0.00 & n.a. & No & \\
\hline Central African Rep. & 0.15 & 0.00 & 1310 & Yes & African; LLDC \\
\hline Burundi & 0.16 & 0.00 & 680 & Yes & African; LLDC \\
\hline Sierra Leone & 0.21 & 0.00 & 450 & Yes & African; LLDC \\
\hline Gambia, The & 0.26 & 0.00 & 1970 & Yes & African; LLDC \\
\hline Bhutan & 0.29 & 0.00 & n.a. & No; accession in progress & LLDC \\
\hline Djibouti & 0.35 & 0.00 & 2350 & Yes & African; LLDC \\
\hline Rwanda & 0.44 & 0.01 & 1190 & Yes & African; LLDC \\
\hline Maldives & 0.45 & 0.01 & n.a. & Yes & LLDC \\
\hline Chad & 0.45 & 0.01 & 1010 & Yes & African; LLDC \\
\hline Niger & 0.46 & 0.01 & 850 & Yes & African; LLDC \\
\hline Eritrea & 0.50 & 0.01 & 960 & No & African; LLDC \\
\hline Mauritania & 0.51 & 0.01 & 1870 & Yes & African; LLDC \\
\hline Togo & 0.60 & 0.01 & 1660 & Yes & African; LLDC \\
\hline Benin & 0.63 & 0.01 & 950 & Yes & African; LLDC \\
\hline Kyrgyz Republic & 0.65 & 0.01 & 2670 & Yes & \\
\hline Malawi & 0.66 & 0.01 & 590 & Yes & African; LLDC \\
\hline Burkina Faso & 0.66 & 0.01 & 1080 & Yes & African; LLDC \\
\hline Suriname & 0.72 & 0.01 & n.a. & Yes & \\
\hline Lesotho & 0.76 & 0.01 & 2320 & Yes & African; LLDC \\
\hline Guyana & 0.79 & 0.01 & 4560 & Yes & \\
\hline Mongolia & 0.79 & 0.01 & 1720 & Yes & \\
\hline Tajikistan & 0.86 & 0.01 & 1100 & Yes & \\
\hline Guinea & 0.89 & 0.01 & 1910 & Yes & African; LLDC \\
\hline Congo, Dem. Rep. of & 0.91 & 0.01 & 730 & Yes & African \\
\hline Mali & 0.92 & 0.01 & 780 & Yes & African; LLDC \\
\hline Armenia & 0.97 & 0.01 & 2420 & Yes & \\
\hline Moldova & 0.97 & 0.01 & 2050 & Yes & \\
\hline Zambia & 1.02 & 0.01 & 760 & Yes & African; LLDC \\
\hline Fiji & 1.03 & 0.01 & 4730 & Yes & \\
\hline Swaziland & 1.10 & 0.01 & 4330 & Yes & African \\
\hline Georgia & 1.21 & 0.02 & 2400 & Yes & \\
\hline Haiti & 1.32 & 0.02 & 1920 & Yes & African \\
\hline
\end{tabular}

Source: World Banks's World Development Indicators; and WTO http://www.wto.org/english/thewto elacc e.htm 
Table 1 (concluded). Small and Poor Countries, 2000

\begin{tabular}{|c|c|c|c|c|c|}
\hline Country & Imports of & goods and services & Per Capita & WTO & Category $1 /$ \\
\hline & (in \$ bn.) & (share of world) & GDP (PPP) & member & \\
\hline Congo, Republic of & 1.40 & 0.02 & 950 & Yes & African; LLDC \\
\hline Uganda & 1.41 & 0.02 & 1450 & Yes & African; LLDC \\
\hline Madagascar & 1.47 & 0.02 & 810 & Yes & African; LLDC \\
\hline Albania & 1.52 & 0.02 & 3500 & Yes & \\
\hline Mozambique & 1.53 & 0.02 & 1000 & Yes & African; LLDC \\
\hline Senegal & 1.73 & 0.02 & 1450 & Yes & African \\
\hline Nepal & 1.78 & 0.02 & 1280 & No; accession in progress & \\
\hline Sudan & 1.87 & 0.02 & 2000 & No; accession in progress & African; LLDC \\
\hline Zimbabwe & 1.96 & 0.02 & 2540 & Yes & African \\
\hline Ethiopia & 1.96 & 0.02 & 770 & No; accession in progress & African; LLDC \\
\hline Cambodia & 2.01 & 0.03 & 1760 & No; accession in progress & LLDC \\
\hline Azerbaijan & 2.02 & 0.03 & 2830 & No; accession in progress & \\
\hline Tanzania & 2.10 & 0.03 & 510 & Yes & African; LLDC \\
\hline Bolivia & 2.24 & 0.03 & 2310 & Yes & \\
\hline Turkmenistan & 2.34 & 0.03 & 3670 & No & \\
\hline Cameroon & 2.38 & 0.03 & 1640 & Yes & African \\
\hline Uzbekistan & 2.96 & 0.04 & 2360 & No; accession in progress & \\
\hline West Bank/Gaza Strip & 3.09 & 0.04 & n.a. & No & \\
\hline Yemen, Republic of & 3.29 & 0.04 & 800 & No; accession in progress & LLDC \\
\hline Honduras & 3.31 & 0.04 & 2830 & Yes & African; LLDC \\
\hline Ghana & 3.46 & 0.04 & 2190 & Yes & African \\
\hline Côte d'Ivoire & 3.50 & 0.04 & 1550 & Yes & African \\
\hline Kenya & 3.77 & 0.05 & 980 & Yes & African \\
\hline Serbia and Montenegro & 4.00 & 0.05 & n.a. & No; accession in progress & \\
\hline Ecuador & 4.19 & 0.05 & 3170 & Yes & \\
\hline Jamaica & 4.33 & 0.05 & 3590 & Yes & \\
\hline Lao People's Dem. Rep & n.a. & n.a. & 1520 & No; accession in progress & LLDC \\
\hline Solomon Islands & n.a. & n.a. & 2160 & Yes & LLDC \\
\hline Papua New Guinea & n.a. & n.a. & 2710 & Yes & \\
\hline Vanuatu & n.a. & n.a. & 3490 & No; accession in progress & LLDC \\
\hline Equatorial Guinea & n.a. & n.a. & n.a. & No; observer & African; LLDC \\
\hline Kiribati & n.a. & n.a. & n.a. & No & LLDC \\
\hline Marshall Islands, Rep & n.a. & n.a. & n.a. & No & \\
\hline Micronesia, Fed. Sts. & n.a. & n.a. & n.a. & No & \\
\hline Somalia & n.a. & n.a. & n.a. & No & African; LLDC \\
\hline Tonga & n.a. & n.a. & n.a. & No; accession in progress & \\
\hline Afghanistan, I.S. of & n.a. & n.a. & n.a. & No & LLDC \\
\hline
\end{tabular}

1/ LLDC stands for least developed country. 
This paper suggests that the system faces a stark reality: desirable ways of accommodating the concerns of the small and poor countries are proving politically infeasible, and, as a result, the system is gravitating toward feasible, but less desirable, options. The desirable manner of addressing their concerns would involve providing small and poor countries compensation in the form of improved nonpreferential access and increased financial and technical assistance, in return for their consenting to the system moving forward with the broader liberalization agenda, as well as a quid pro quo for their own liberalization efforts.

Because addressing discontent through positive financial and market access compensation is difficult, the system is gravitating towards another option: relieving these countries of obligations they see as impositions and thus eliminating the basis of their opposition to continued multilateral liberalization. While clearly inferior to the alternative of positive compensation, it is not in fact a radical solution to the current impasse but merely a reversion to the two-tier, pre-Uruguay system, albeit with changed actors: the second tier occupied by today's small and poor countries just as it was occupied pre-Uruguay Round by the then poor and small countries.

This paper is organized as follows. Section II traces the history of the current challenge in regard to the small and poor countries in the WTO. Section III examines their growing influence. Section IV describes the consequences in the WTO of being small. Section V examines the extent to which the interests of the small and poor countries are aligned with those of the system. Section VI enumerates and evaluates the different ways in which the concerns of the small and poor countries can be addressed, while Section VII concludes.

\section{How Did We Get Here?}

In the period until the launch of the Uruguay Round and the formation of the WTO, only the industrial countries were meaningful participants in multilateral trade negotiations. They bargained amongst themselves to reduce trade barriers, while developing countries were largely out of this process and had few obligations to liberalize. The latter availed themselves of the benefits of industrial country liberalization, courtesy of the Most Favored Nation (MFN) principle, but that defined pretty much the limits of their contribution to or benefits from the General Agreement on Tariffs and Trade (GATT).

Industrial countries were content with this arrangement, in part because it alleviated the pressure on them to liberalize sensitive sectors such as agriculture and clothing, but perhaps more importantly because the markets of developing countries were not at that stage sufficiently attractive. It did not really matter enough to the industrial countries to exert pressure on developing countries to liberalize: the benefits were smaller than the costs of having to liberalize their own labor-intensive sectors.

As development and globalization proceeded apace through the 1980s, hitherto "small" developing countries started growing in size and started becoming attractive to industrial country exporters as markets. This "shock" of the economic transformation of a large number of developing countries meant that the previous equilibrium whereby developing countries were left out of the GATT process needed to be revisited. This underlay the loaded rhetoric 
during the Uruguay Round that developing countries were free riders in the system, extracting the benefits from MFN and offering little by way of their own liberalization. ${ }^{4}$

The Uruguay Round was then precisely the required adjustment to this shock and established a new "equilibrium." The larger developing countries were brought into the fold because their markets started to matter and had to take on many of the obligations of industrial countries. The two-tiered approach was abandoned to create a symmetry of obligations between all members. For the larger developing countries, the process of establishing this new equilibrium was to some extent consistent with the WTO reciprocity principle. The Uruguay Round, warts and all, did involve a reciprocal bargain for the larger developing countries: they made concessions on intellectual property and in return got market opening concessions in textiles and clothing and, to a lesser extent, in agriculture.

However, in one very important respect there may have been overshooting. Driven by the heady, headlong embrace of the globalization mantra, the Uruguay Round brought into the system not only the larger developing countries, whose markets mattered, but also the smaller developing countries whose markets did not really matter. This "overshooting" because of the single undertaking has created today's challenge of accommodating these countries into the system. The question now is whether this accommodation can be done in ways that improve the welfare of these small countries and keep them engaged in the system. Or whether, if that proves infeasible, there will be a reversion to the two-tier system preUruguay Round, albeit with changed actors: the second tier being occupied by today's small and poor countries.

\section{The Growing INFLuenCe, ItS BASIS, AND CONSEQUENCES}

\section{A. Manifestations of Influence}

Ever since the conclusion of the Uruguay Round, the small and poor countries have acquired a measure of voice or influence in the trading system that has grown over time. The concerns of developing countries were an important element of the disagreements leading up to and at Seattle. These concerns - the so-called implementation issues - related largely to the developing countries' perceptions that the Uruguay Round was unfair and had imposed onerous obligations on these countries.

The launch of the Doha Round was similarly influenced by the concerns of developing countries. Two manifest overtures aimed at addressing these concerns and buying off developing country opposition to the launching of the Doha Round were, first, the Everything But Arms (EBA) initiative of the European Union, and later the inclusion in the Doha Round declaration of a formal waiver for preferential schemes such as the Cotonou Agreement. Second, the Doha declaration contained an explicit undertaking to address one

\footnotetext{
${ }^{4}$ Of course, to the extent that some of these countries had liberalized unilaterally, the issue was locking in these reforms in the WTO.
} 
of the key sources of Uruguay Round discontent, namely the Trade-Related Intellectual Property Rights (TRIPs) agreement.

Leading up to Cancun, developing countries' concerns were once again seen to be important. The inability to tackle the cotton subsidy that adversely affects the poor countries in West Africa as well as the generalized opposition on the part of small countries to the Singapore issues were clear examples of how these countries are beginning to articulate effectively their collective interests.

Of course, how strong this influence is and whether it can result in blocking coalitions is far from clear. Even at Cancun, if the bigger trading nations had been able to resolve differences over agriculture, opposition from the poor countries probably would have been overcome. Nevertheless, the fact of the growing influence is undeniable and we examine the consequences if the demands that arise from it are not addressed.

\section{B. Basis}

This growing influence has both de jure and de facto dimensions. The WTO has a strong tradition of taking all decisions by consensus. Formally, though, the Agreement Establishing the WTO provides that most decisions in the WTO can be legally made with either a twothirds or three-fourths majority depending on the nature of the decision being considered. Moreover, decisions to create new plurilateral agreements (that is, agreements that apply only between a subset of the WTO membership) can only be taken by consensus. Thus, small countries that now comprise more than 50 percent of the membership of the WTO, have de jure veto power.

It is worth examining in some detail the areas or decisions over which de jure power can be exercised in the context of the Doha Round. Enlarging the scope of the WTO to include new issues such as investment and competition policies would amount to amending the WTO, which would require a two-thirds majority. In addition, if these agreements are going to be plurilateral, the consensus rule would effectively confer veto power on small countries.

The deepening of rules in the Doha Round - for example, changes to the anti-dumping and subsidies agreements and strengthening the framework of GATT and GATS rules - would also constitute an amendment to the WTO, which would require consent by two-thirds of the membership.

One area where the small countries may have less de jure power relates to further market access liberalization, which could in principle be undertaken by those who wish to proceed without requiring the consent of others. Thus, further tariff cuts, elimination of agricultural subsidies, and deepening market access commitments in services could be agreed in the Doha Round without the small and countries being able to block them.

More importantly perhaps, small countries have acquired considerable de facto influence. This influence has emanated, in some considerable part, from the fact that small countries have been required to take on a number of obligations relating to liberalization, institutional 
upgradation, and intellectual property rights protection in the Uruguay Round, which have been perceived as extremely costly. If we have obligations - especially costly ones-we must have a commensurate say in the business of the WTO has been their implicit argument.

But is this influence - traced back to their sense of being unfairly treated by their having to adhere to the single undertaking of the Uruguay Round - unique to the small and poor countries and if so why? The answer is in the affirmative. We described above that small and poor countries had to undertake "costly" obligations in the Uruguay Round. However, so too did the larger developing countries. Nevertheless, there were important differences relative to the smaller ones. First, on TRIPs, although the adverse consequences in the area of pharmaceuticals affect both groups equally, larger developing countries that had indigenous manufacturing capability had the wherewithal to mitigate TRIPs' worst impact through the use of compulsory licensing. The small countries did not have this option and were hence more vulnerable to TRIPs. 5

Second, implementing agreements like the Customs Valuation Agreement was also less onerous for the richer developing countries and arguably also closer to their own development priorities. For the poorer countries, the costs incurred in implementing these agreements were less consonant with overall development priorities.

However, perhaps the most significant difference between the two sets of countries was that the larger developing countries received reciprocal concessions in the form of market opening in clothing and agriculture. By virtue of being large and attractive to trading partners as markets, the larger developing countries were able to secure these concessions. For the smaller countries, these concessions did not amount to much because of their status as preferential exporters. Indeed, from their perspective, the elimination of the MFA, which was de facto a large scheme of preferences for the smaller countries that tended to be higher cost suppliers, was a loss rather than a gain. This lack of an offset on the market access side led them to the perception that the single undertaking was onerous.

Small country discontent with the Uruguay Round has therefore been an issue in the WTO ever since the conclusion of the Uruguay Round and has manifested itself in the so-called implementation issues leading up to Seattle and in discussions of special and differential treatment (S\&D) leading up to Doha and Cancun.

\section{Consequences}

The de jure power of the small and poor countries would allow them to block any outcome in the Doha Round that relates to the deepening of rules or widening the scope of the WTO. It may not empower them to impede progress in the market access areas in goods and services.

\footnotetext{
${ }^{5}$ The agreement reached in Geneva in August 2003 was in fact a recognition as well as a means of addressing this differential impact of TRIPs on the small and poor countries.
} 
Nevertheless, it is the de facto power of the small and poor countries that is perhaps more relevant in shaping the outcome of the Doha Round. Their persistent dissatisfaction, in an intellectual and political climate that is so geared to ensuring a fair outcome for these countries, cannot be ignored. The challenge therefore for the trading system is to find ways of accommodating their interests both for its own sake but also for smoother and expeditious progress in the Doha Round.

\section{SIZE AND THE BENEFITS FROM WTO MEMBERSHIP}

In principle, the WTO offers three benefits to a country: enhanced market access for its exports; an impetus to its own trade reform; and a commitment to good trade policy. How does size affect these benefits?

\section{A. Promoting Access to Foreign Markets}

A WTO member benefits in principle by getting increased access for its exports to the markets of its trading partners. However, for several reasons, small and poor countries have little ability to influence WTO-based market opening.

The market access benefit is realized in the WTO in a very particular way: countries negotiate access on a reciprocal basis. For a country to gain from increased market access it must be willing to open its own market and, more importantly, this market opening must be sufficiently attractive for partner countries to be willing to engage in negotiations. It is a sad but unavoidable reality of the mercantilist underpinnings of the WTO that countries with small markets are inherently disadvantaged in the reciprocity process because they are not attractive enough to trading partners.

Table 1 lists the small and poor countries by their share in world imports of goods and services. All 62 countries on the list for which data are available individually account for less than 0.05 percent of world trade, and collectively for about 1.1 percent of global trade. These countries are therefore structurally disadvantaged in negotiating market access.

\section{B. WTO to Promote and Lock in Liberalization}

One of the major aims of the WTO is to promote the dismantling of trade barriers by member countries. But as discussed above, this dismantling occurs through a process of reciprocal concessions, whereby one country lowers its barriers in return for similar actions by its trading partners. If a country is small, its trading partners may not find it worthwhile to engage in this bargaining.

The history of the GATT and the WTO suggest that, as a factual matter, the multilateral trading system has had very little impact in furthering trade liberalization in developing countries. In terms of tariff reductions, the Uruguay Round did not have much impact even 
on the larger developing countries, let alone the smaller countries. In the vast majority of cases, small countries had few bindings (see Table 2), which by definition involves no requirement to liberalize, and even where they did (for example in agriculture), the bound rates were so high relative to prevailing applied rates that no cuts in the latter were required.

The WTO can serve as a device for committing to good policies. External commitments can foster good policies in two respects: providing guarantees against reversal of current policies and credibly promising future reform. Thus, binding tariffs close to applied rates has in some countries prevented the reversal of tariff liberalization. A number of countries have also used multilateral commitments to lend credibility to future reform programs, e.g. in sectors such as telecommunications. Such precommitment can help strike a balance between the reluctance to unleash competition immediately and the desire not to be held hostage in perpetuity to the weakness of domestic industry or the power of vested interests.

What has been the record of the WTO in furthering good policies by developing countries? Table 2 sheds light on this question for trade in goods. It lists the extent to which countries undertook commitments not to reverse their tariffs in the area of trade in goods. These commitments comprise both the share of imports covered by bindings - and for those imports where such commitments were undertaken also the wedge between actual tariffs and the level of the committed tariff. As the Table shows, for a vast majority of the poor and small countries, both the proportion of bindings in the industrial sector is small and the wedge between actual and committed tariffs is large, indicating that countries have given themselves a large margin of flexibility to reverse their trade policies without facing adverse consequences in the WTO. ${ }^{6}$ The same broad picture also emerges in trade in services. The GATS, apart from in basic telecommunications and in the case of acceding countries, has not been effective in encouraging countries to undertake reform and in limiting their freedom to reverse it.

There is the interesting question as to why these countries allowed themselves this freedom if they really wished to use the WTO as a commitment device or as an anchor for good policies. However, an even more interesting question is why their trading partners allowed these countries such freedom given the uncertainty it can generate for their own export opportunities? The answer is in part related to the reasons we have suggested earlier. Countries with small markets are just not attractive enough for larger trading partners to engage in meaningful reciprocity negotiations. They simply may not care! In addition, if they do not, the value of the WTO as a precommitment device is undermined because trading partners do not enforce the policy commitments undertaken by the smaller countries.

\footnotetext{
${ }^{6}$ Under the Uruguay Round, all countries, including developing countries were required to bind all their agricultural tariffs but were allowed to bind them at very high, often meaninglessly high, levels. The latter is reflected in the data on the wedge in the agricultural sector.
} 
Table 2. Average and Bound Tariff Rates for Small and Poor WTO Members

\begin{tabular}{|c|c|c|c|c|c|c|c|c|c|c|c|}
\hline \multirow[b]{2}{*}{ Country } & \multicolumn{4}{|c|}{ Total Goods } & \multicolumn{4}{|c|}{ Industry } & \multicolumn{3}{|c|}{ Agriculture* } \\
\hline & $\begin{array}{l}\text { Binding } \\
\text { coverage } \\
\text { (percent) }\end{array}$ & $\begin{array}{c}\text { Average } \\
\text { Bound Rate }\end{array}$ & $\begin{array}{c}\text { Average } \\
\text { Applied } \\
\text { Rate }\end{array}$ & Wedge & $\begin{array}{l}\text { Binding } \\
\text { coverage } \\
\text { (percent) }\end{array}$ & $\begin{array}{c}\text { Average } \\
\text { Bound Rate }\end{array}$ & $\begin{array}{c}\text { Average } \\
\text { Applied } \\
\text { Rate }\end{array}$ & Wedge & $\begin{array}{c}\text { Average } \\
\text { Bound Rate }\end{array}$ & $\begin{array}{c}\text { Average } \\
\text { Applied } \\
\text { Rate }\end{array}$ & Wedge \\
\hline - & (1) & (2) & (3) & (2)-(3) & (5) & (6) & (7) & (6)-(7) & (8) & (9) & (8)-(9) \\
\hline Albania & 100.00 & 6.99 & 7.80 & -0.81 & 100.00 & 6.63 & 6.95 & -0.32 & 9.37 & 10.72 & -1.35 \\
\hline Armenia & .. & .. & .. & .. & .. & .. & .. & .. & .. & .. & .. \\
\hline Benin & 39.40 & 28.35 & 14.70 & 13.65 & 30.10 & 11.39 & 14.10 & -2.71 & 61.77 & 15.50 & 46.27 \\
\hline Bolivia & 100.00 & 39.98 & 9.10 & 30.88 & 100.00 & 39.98 & 9.05 & 30.93 & 39.98 & 10.00 & 29.98 \\
\hline Burkina Faso & 39.20 & 41.86 & 12.80 & 29.06 & 29.90 & 13.15 & 12.60 & 0.55 & 98.12 & 14.80 & 83.32 \\
\hline Burundi & 21.80 & 68.34 & 7.40 & 60.94 & 9.90 & 26.83 &.. & .. & 95.36 & .. & .. \\
\hline Cameroon & 13.30 & 79.87 & 18.30 & 61.57 & 0.10 & 50.00 & 17.30 & 32.70 & 80.00 & 23.69 & 56.31 \\
\hline Central African Rep. & 62.50 & 36.20 & 18.40 & 17.80 & 56.80 & 37.87 & 17.50 & 20.37 & 30.00 & 24.90 & 5.10 \\
\hline Chad & 13.50 & 79.92 & 17.00 & 62.92 & 0.20 & 75.42 & 16.70 & 58.72 & 80.00 & 21.00 & 59.00 \\
\hline Congo, Dem. Rep. & 100.00 & 96.24 & 17.60 & 78.64 & 100.00 & 95.94 & .. & .. & 98.21 & .. & .. \\
\hline Congo, Rep. & 16.00 & 27.47 & 18.60 & 8.87 & 3.10 & 15.21 & 17.20 & -1.99 & 30.00 & 24.00 & 6.00 \\
\hline Cote d'Ivoire & 33.10 & 11.15 & 12.60 & -1.45 & 22.90 & 8.62 & 12.30 & -3.68 & 14.94 & 14.50 & 0.44 \\
\hline Djibouti & 100.00 & 41.04 & 30.92 & 10.12 & 100.00 & 40.04 & 31.52 & 8.52 & 47.60 & 25.29 & 22.30 \\
\hline Ecuador & 99.80 & 21.72 & 11.31 & 10.41 & 99.80 & 21.14 & 10.66 & 10.48 & 25.50 & 14.51 & 11.00 \\
\hline Fiji & 52.20 & 40.10 & 12.40 & 27.70 & 45.00 & 40.00 & 12.40 & 27.60 & 40.39 & 14.30 & 26.09 \\
\hline Gambia, The & 13.60 & 100.94 & 13.60 & 87.34 & 0.50 & 56.36 &.. & .. & 102.42 &.. & .. \\
\hline Georgia & 100.00 & 7.17 & 9.90 & -2.73 & 100.00 & 6.50 & 9.50 & -3.00 & 11.73 & 11.70 & 0.03 \\
\hline Ghana & 14.30 & 92.44 & 14.70 & 77.74 & 1.20 & 34.72 & 13.80 & 20.92 & 97.14 & 20.20 & 76.94 \\
\hline Guinea & 38.90 & 20.12 & 6.24 & 13.87 & 29.50 & 10.00 & 6.22 & 3.78 & 39.70 & 6.45 & 33.25 \\
\hline Guinea-Bissau & 97.70 & 48.65 & 14.00 & 34.65 & 97.30 & 50.00 & 13.30 & 36.70 & 40.00 & 17.00 & 23.00 \\
\hline Guyana & 100.00 & 56.65 & 11.56 & 45.10 & 100.00 & 50.04 & 9.74 & 40.30 & 100.00 & 23.76 & 76.24 \\
\hline Haiti & 89.20 & 17.61 & 10.00 & 7.61 & 87.60 & 16.86 & .. & .. & 21.72 & .. & .. \\
\hline Honduras & 100.00 & 32.54 & 7.47 & 25.07 & 100.00 & 32.58 & 6.67 & 25.91 & 32.29 & 11.80 & 20.49 \\
\hline Jamaica & 100.00 & 49.77 & 8.90 & 40.87 & 100.00 & 42.52 & 6.43 & 36.09 & 97.40 & 17.33 & 80.07 \\
\hline Kenya & 14.60 & 95.61 & 17.10 & 78.51 & 1.60 & 54.14 & 16.53 & 37.61 & 100.00 & 20.64 & 79.36 \\
\hline Kyrgyz Republic & 99.90 & 7.42 & 4.34 & 3.08 & 99.90 & 6.68 & 4.04 & 2.64 & 12.32 & 7.41 & 4.91 \\
\hline Lesotho & 100.00 & 78.55 & 17.40 & 61.15 & 100.00 & 60.02 & .. & .. & 200.00 & .. & .. \\
\hline Madagascar & 29.70 & 27.41 & 6.01 & 21.40 & 18.90 & 25.33 & 6.07 & 19.26 & 30.00 & 5.61 & 24.39 \\
\hline Malawi & 26.10 & 82.74 & 13.57 & 69.17 & 14.90 & 43.32 & 13.24 & 30.08 & 121.27 & 18.55 & 102.72 \\
\hline Maldives & 97.10 & 36.91 & 22.10 & 14.81 & 96.60 & 35.20 & 22.20 & 13.00 & 47.81 & 17.90 & 29.91 \\
\hline Mali & 40.60 & 28.82 & 11.24 & 17.58 & 31.60 & 14.15 & 10.40 & 3.75 & 59.17 & 16.06 & 43.11 \\
\hline Mauritania & 39.30 & 19.64 & 10.60 & 9.04 & 30.00 & 10.48 & 10.00 & 0.48 & 37.67 & 13.80 & 23.87 \\
\hline Moldova & 100.00 & 6.70 & .. & .. & 100.00 & 6.00 & .. & .. & .. & .. & .. \\
\hline Mongolia & 100.00 & 17.55 & 8.20 & 9.35 & 100.00 & 17.35 & .. & .. & 18.89 & .. & .. \\
\hline Mozambique & 13.60 & 97.50 & 13.80 & 83.70 & 0.40 & 6.60 & 12.50 & -5.90 & 100.00 & 18.10 & 81.90 \\
\hline Niger & 96.80 & 44.29 & 14.50 & 29.79 & 96.20 & 38.13 & 14.40 & 23.73 & 83.09 & 15.10 & 67.99 \\
\hline Papua New Guinea & 100.00 & 31.67 & 8.80 & 22.87 & 100.00 & 30.03 & 8.00 & 22.03 & 43.15 & 24.60 & 18.55 \\
\hline Rwanda & 100.00 & 89.28 & 10.00 & 79.28 & 100.00 & 91.54 & 9.20 & 82.34 & 74.38 & 13.20 & 61.18 \\
\hline Senegal & 100.00 & 29.97 & 12.08 & 17.89 & 100.00 & 29.99 & 11.57 & 18.42 & 29.84 & 14.69 & 15.15 \\
\hline Sierra Leone & 100.00 & 47.30 & 21.00 & 26.30 & 100.00 & 48.38 & .. & .. & 40.18 & .. & .. \\
\hline Solomon Islands & 100.00 & 78.63 & 22.31 & 56.32 & 100.00 & 79.88 & 20.73 & 59.15 & 70.20 & 38.64 & 31.57 \\
\hline Suriname & 26.30 & 18.46 & 15.30 & 3.16 & 15.10 & 17.04 & .. & .. & 19.87 &.. & .. \\
\hline Swaziland & 96.40 & 19.10 & 15.10 & 4.00 & 96.00 & 15.84 & .. & .. & 38.36 & .. & .. \\
\hline Tanzania & 13.30 & 120.00 & 16.10 & 103.90 & 0.10 & 120.00 & 16.10 & 103.90 & 120.00 & 17.40 & 102.60 \\
\hline Togo & 13.70 & 80.00 & 12.13 & 67.87 & 0.60 & 80.00 & 11.62 & 68.38 & 80.00 & 15.09 & 64.91 \\
\hline Uganda & 15.70 & 73.27 & 8.79 & 64.48 & 2.90 & 50.39 & 8.39 & 42.00 & 77.69 & 12.54 & 65.15 \\
\hline Zambia & 16.80 & 106.38 & 13.49 & 92.89 & 4.00 & 42.69 & 12.61 & 30.08 & 123.32 & 18.15 & 105.17 \\
\hline Zimbabwe & 21.00 & 94.26 & 18.78 & 75.47 & 8.90 & 10.97 & 17.32 & -6.35 & 143.47 & 27.67 & 115.80 \\
\hline Average & 61.82 & 50.56 & 13.44 & 38.08 & 55.99 & 36.51 & 12.67 & 23.96 & 64.44 & 17.21 & 45.75 \\
\hline
\end{tabular}

Note: Based on the latest available data on WTO files

Source: WTO IDB \& CTS databases and IDB CD-ROM 2002.

(*) For Agriculture, binding coverage is $100 \%$ for all WTO Members. 


\section{IMPERFECT ALIGNMENT OF INTERESTS}

How aligned are the interests of the small and poor countries with that of the system? In other words, what would be the welfare consequences to them of the nondiscriminatory elimination of trade barriers in the WTO?

First, many of the small and poor countries benefit from preferential access to their main trading partners (see Table 3). As developing countries, they receive preferences under the Generalised System of Preferences (GSP) in the European Union, United States, Japan, and Canada; as African Carribean Pacific (ACP) members of the Cotonou Agreement they receive greater preferential access to EU markets; as least developed countries (LLDCs) they receive virtually duty and quota-free access in the European Union (under the Everything But Arms Initiative (EBA)), and Canada; as African countries they receive virtual duty and quota-free access in the United States under the Africa Growth and Opportunity Act (AGOA).

The impact on preference-receiving countries of MFN tariff liberalization is illustrated by the analysis of Iancovicina et al. (2002). They estimate that (i) if 37 sub-Saharan African countries were to receive completely unrestricted preferential access to the markets of the Quad countries (European Union, United States, Japan, and Canada), their welfare would increase by about $\$ 1.7$ billion; and (ii) a 25 percent MFN tariff liberalization by the Quad countries will, by eroding the preference margins received by these countries, reduce the welfare increase in (i) above by about $\$ 0.5$ billion or about 30 percent.

However, this finding might overstate the loss in welfare due to MFN liberalization for several reasons. First, not all small and poor countries are covered by the generous provisions of the EU's EBA and the U.S.' AGOA. Second, even under AGOA, onerous rules-of-origin and burdensome standards limit the benefits that countries derive from preferential access. Third, the rents from preferential access may also in part be appropriated by importers rather than exporters (Olarreaga and Ozden, 2003). Fourth, there are areas where these countries do not receive preferential access, for example, in Japan for agricultural products (because the GSP excludes these products) and in other developing countries for agricultural and manufactured products.

Finally, when the instrument of protection is subsidies, the question of preferential access does not arise. The best example of alignment, of course, is cotton, where a number of small and poor countries in West Africa suffer as a result of market access barriers in industrial countries. Cancun, perhaps for the first time, witnessed the emergence of small countries as serious demandeurs for improved nonpreferential market access. 
Table 3. Tariffs Under Preferential Schemes

\begin{tabular}{lcc}
\hline \multicolumn{1}{c}{ Preferential Agreement } & $\begin{array}{c}\text { Average tariff rate } \\
\text { (all HS-6 products) }\end{array}$ & $\begin{array}{c}\text { Average tariff rate } \\
\text { (tariff peak products) }\end{array}$ \\
\hline Canada & & \\
GSP & 4.3 & 28.2 \\
LDCs 1/ & 4.4 & 22.8 \\
MFN & 8.3 & 30.5 \\
European Union & & \\
GSP & 3.6 & 19.8 \\
LDC ACP 2/ & $0.8(0)$ & $\sim 0$ \\
Non-LDC ACP 2/ & 0.9 & $\sim 0$ \\
MFN & 7.4 & 40.3 \\
& & \\
Japan & 2.3 & 22.7 \\
GSP & 1.7 & 19.0 \\
LDCs & 4.3 & 27.8 \\
MFN & & \\
United States & 2.4 & 16 \\
GSP & 0.0 & n.a. $(\sim 0)$ \\
AGOA LDCs 3/ & 1.8 & 14.4 \\
Non-AGOA LDCs & 5.0 & 20.8 \\
MFN & &
\end{tabular}

Sources: Hoekman, Ng, and Olarreaga (2002) and Fund staff estimates.

1/ Does not reflect the recent Canadian initiative with regard to LDCs' exports.

2/ Estimates for the European Union's preference schemes for LDCs are for the post-EBA regime. They assume that the EBA will provide unrestricted access at the end of the transitional period.

3/ Estimates for AGOA are based on Mattoo, Roy, and Subramanian (2002). 
Nevertheless, even in regard to subsidies, there is imperfect alignment in the area of food imports. ${ }^{7}$ A number of countries on our list are net importers of food: 42 out of the 71 small and poor countries for which we have data and 26 out of 48 WTO members are net food importers (see Table 4). These countries are potentially vulnerable to losses if the world price of food rises as a result of agricultural liberalization by the industrial countries. Most studies estimate a rise in food prices of between 4 and 8 percent (Cline, 2004; Tokarick, 2003). ${ }^{8}$

One estimate of the overall effect stemming from policies relating to subsidies is from Hoekman and others (2004). They find, for example, that a 50 percent cut in export subsidies by industrial reduces the welfare of the least developed countries by about 3 cents per capita, and an equivalent cut in domestic support increases welfare by about 3 cents per capita. Thus, the overall impact of liberalization of nontariff agricultural support policies on the smaller countries is negligible.

The imperfect alignment also relates to WTO obligations other than those that involve conventional market liberalization and commitment that we have already discussed earlier, which can be of two kinds (see Hoekman and others 2003). First, there are obligations that may have positive welfare consequences in themselves but whose implementation entails significant financial costs. In the Uruguay Round, the customs valuation fell in this category. For example, Finger and Schuler (2002) argue that the costs of implementing such agreements amounted to as much as US\$300 million. In the Doha Round, some of the socalled Singapore issues, for example, rules on trade facilitation, would fall in this category. Second, another set of obligations may entail unambiguously negative welfare and financial consequences. In the Uruguay Round, the TRIPs agreement was a good example of this type of obligation. ${ }^{9}$

How does our claim regarding the limited nature of benefits from MFN liberalization for small and poor countries square with recent studies (World Bank, 2003; Cline, 2004) that show large reductions in poverty (150-300 million) in the developing world from a successful Doha Round?

\footnotetext{
${ }^{7}$ Small and poor countries are more likely to be net exporters of nonfood agricultural products than of food products. However, nonfood agricultural exports generally face low trade barriers in major industrial country markets.

${ }^{8}$ Cline (2004) in his study, however, argues that net food importers could nevertheless benefit from global trade liberalization as long as they are proportionally larger net importers of manufacturing than agricultural products. Global liberalization, according to him, will lead to a reduction in the world price of manufactures relative to agricultural products that will have a positive welfare impact.

${ }^{9}$ See Chaudhri and others (2003) for estimates of the impact of TRIPs on India.
} 
Table 4. Net Food Imports of Small and Poor Countries

(Exports minus imports in US\$ millions in 2001)

\begin{tabular}{|c|c|}
\hline Country & Net Food Exports \\
\hline Afghanistan & -149.9 \\
\hline Armenia* & -37.7 \\
\hline Azerbaijan & -202.9 \\
\hline Benin* & -204.3 \\
\hline Bhutan & -2.6 \\
\hline Bolivia* & 181.4 \\
\hline Burkina Faso* & -27.8 \\
\hline Burundi* & 11.3 \\
\hline Cambodia & -262.5 \\
\hline Cameroon* & 217.1 \\
\hline Central African Rep.* & -7.1 \\
\hline Chad* & -21.8 \\
\hline Comoros & -9.7 \\
\hline Congo, Dem. Rep.* & -105.8 \\
\hline Congo, Rep.* & -169.0 \\
\hline Cote d'Ivoire* & $1,690.1$ \\
\hline Djibouti* & -86.9 \\
\hline Ecuador* & $2,489.7$ \\
\hline Equatorial Guinea & -22.3 \\
\hline Eritrea & -48.5 \\
\hline Ethiopia & 128.5 \\
\hline Fiji* & 150.4 \\
\hline Gambia, The* & -80.7 \\
\hline Georgia* & -121.6 \\
\hline Ghana* & 347.7 \\
\hline Guinea* & -102.4 \\
\hline Guinea-Bissau* & -3.9 \\
\hline Guyana* & 160.2 \\
\hline Haiti* & -315.9 \\
\hline Honduras* & 508.0 \\
\hline Jamaica* & -103.3 \\
\hline Kenya* & 630.6 \\
\hline Kiribati & 22.7 \\
\hline Kyrgyz Republic* & -5.9 \\
\hline Lao PDR & -72.0 \\
\hline Lesotho* & 2.0 \\
\hline
\end{tabular}


Table 4 (concluded). Net Food Imports of Small and Poor Countries

\begin{tabular}{|c|c|}
\hline Country & Net Food Exports \\
\hline Madagascar* & 351.2 \\
\hline Malawi* & 326.1 \\
\hline Maldives* & -7.7 \\
\hline Mali* & -98.2 \\
\hline Marshall Islands & 29.6 \\
\hline Mauritania* & 65.0 \\
\hline Micronesia, Fed. Sts. & 55.5 \\
\hline Moldova* & 220.5 \\
\hline Mongolia* & -79.9 \\
\hline Mozambique* & -73.7 \\
\hline Nepal & 95.8 \\
\hline Niger* & -64.7 \\
\hline Palau & 3.5 \\
\hline Papua New Guinea* & 259.1 \\
\hline Rwanda* & -9.0 \\
\hline Sao Tome and Principe & -5.3 \\
\hline Senegal* & -57.0 \\
\hline Serbia and Montenegro & -291.7 \\
\hline Seychelles & 146.8 \\
\hline Sierra Leone* & -63.1 \\
\hline Solomon Islands* & 15.1 \\
\hline Somalia & -75.1 \\
\hline Sudan & -55.5 \\
\hline Suriname* & 21.9 \\
\hline Swaziland* & 166.8 \\
\hline Tajikistan & -57.9 \\
\hline Tanzania* & 219.3 \\
\hline Togo* & -52.9 \\
\hline Tonga & 3.4 \\
\hline Turkmenistan & -55.5 \\
\hline Uganda* & 245.2 \\
\hline Uzbekistan & -70.1 \\
\hline Vanuatu & 10.3 \\
\hline West Bank/Gaza Strip & n.a. \\
\hline Yemen, Republic & -555.5 \\
\hline Zambia* & -10.8 \\
\hline Zimbabwe* & 777.7 \\
\hline
\end{tabular}

Source: WTO IDB \& CTS databases and IDB CD-ROM 2002.

(*) indicates WTO member 
A closer look at these studies suggests that they do not contradict our contention for several reasons. First, for the small and poor countries the gains are over-stated, as the studies do not take into account the negative impact of preference erosion. ${ }^{10}$ Second, a significant part of the benefits arises from the assumed dynamic gains stemming from their own liberalization. Small and poor countries maintain substantial wedges between actual and bound tariffs for reasons related to partner country indifference, as argued above. It is probably unrealistic therefore to expect serious reductions in applied tariffs by small and poor countries in the Doha Round.

This disaggregation between impacts from market access and from own liberalization is quite important in a WTO-reciprocity context. Even if gains from own liberalization are large, there is little reason for countries to implement such liberalization in a WTO context unless there is a substantial or equivalent market access benefit that can offset the political costs of own liberalization. Thus, it is not enough to demonstrate that small and poor countries gain on balance from multilateral liberalization in the WTO: they must also gain significantly in market access terms that would render the WTO a politically useful vehicle to undertake own liberalization. And the evidence, from most studies that take into account the impact of preference erosion, is that these effects - positive or negative - are small.

\section{Accommodating the Small and Poor Countries}

A lingering legacy of unreciprocated burdens from the Uruguay Round forms the background against which the small and poor countries contemplate the Doha Round. Looking ahead, the key questions are whether and how these countries can emerge from the Doha Round with the sense that they have attained a fair balance of benefits and costs.

Accommodating the small and poor countries can occur through some combination of the following possibilities. They can be:

- provided preferential market access benefits in the Doha Round;

- provided nonpreferential market access benefits in the Doha Round;

- spared/relieved of obligations in the Doha Round (and the Uruguay Round) that are either financially costly or welfare-deteriorating for them;

- spared/relieved of obligations in the Doha Round (and the Uruguay Round) that are welfare-enhancing for them;

- provided financial and technical assistance.

${ }^{10}$ The also do not take account of the negative impact stemming from obligations such as TRIPs, and from the financial costs of adhering to agreements such as TRIPS and customs valuation. 
We evaluate these elements individually in terms of their feasibility and desirability and then rank combinations of these elements.

\section{A. Preferential Access}

The problem with granting preferential access in goods trade as the pay-off to small and poor countries is that it is counter-productive and even perverse. ${ }^{11}$ Although preferential access does provide rents in the short run, the empirical evidence suggests that preferences do not provide a basis for sustaining long-run growth (Romalis, 2003). In addition, preferences create an incentive for recipients to have more protectionist regimes (Ozden and Reinhardt, 2003). Furthermore, there is a limit to the preferential access that can be offered, which is fast being approached given the proliferation of preferential schemes. However, quite apart from these facts, preferences actually reinforce the incentives for the small and poor countries to resist MFN liberalization. This has led to the repeated demands that small and poor countries be provided financial assistance for the loss of preferential access from multilateral liberalization. Thus, preferences have been offered ex ante to overcome the opposition to MFN liberalization and then financial assistance is being offered ex post to cushion them against the loss of such access when the MFN liberalization actually takes place. In fact, the IMF is in the process of designing a facility aimed at providing such financial assistance.

Nevertheless, political economy considerations make it easier for countries to grant preferential than nonpreferential access and for recipient countries to resist the dismantling of preferences even though it may be in their interest to do so. Providing preferential access results in a smaller political dislocation in the granting country (in the limit, preferential liberalization by a large country in favor of a small country entails little change in domestic prices and production and all that happens is a diversion of imports from lower cost suppliers to preference-receiving countries). Second, insofar as dislocation does result or is threatened, it can be clawed back through rules-of-origin (See Mattoo and others (2003) for the impact of rules-of-origin in the case of AGOA).

Similarly, in the recipient country, the beneficiaries of preferential access become politically powerful on account of the large rents that they have reaped. They have a large stake in resisting the erosion of these rents and the ability to do so by virtue of having accumulated them for many years. Thus, although the country may have a long-run interest in aligning incentives with long-run comparative advantage, and hence move away from reliance on preferences, the power of preferential exporters might impede such a move.

${ }^{11}$ One area where preferential access might be worth pursuing is with regard to the temporary movement of unskilled labor. There seems to be little prospect of multilateral liberalization of such movement, while there is evidence of a willingness on the part of some industrial countries to conclude bilateral agreements with specific developing countries. Here the role of the WTO would be to acquiesce in the participation of the small countries in such agreements despite the implied departure from the MFN principle. 


\section{B. Nonpreferential Access}

Providing improved nonpreferential access to the small and poor countries is desirable. However, because these countries are small, they cannot, through the normal reciprocity process, secure increased market access beyond levels negotiated by larger countries. They are unable to offer their trading partners market access benefits that would make the lowering of barriers politically easier for the latter. In other words, larger trading partners would have to offer unreciprocated concessions outside the bargaining dynamic of the WTO. The impasse over the cotton subsidy at Cancun reflected in part this asymmetry, with the small West African countries unable to offer additional concessions that would enable the United States to reduce the subsidy.

The same argument applies to the reduction of barriers in developing countries, which currently impede the exports of the small and poor countries. Larger developing countries would find it politically difficult to reduce their trade barriers for the sake of the small countries without receiving offsetting benefits.

\section{Limiting Costly Obligations}

The case for exempting small and poor countries from obligations that are welfarediminishing (such as TRIPs) and are financially costly (such as the Customs Valuation agreement in the Uruguay Round and the Singapore issues in the Doha Round) is obvious and strong.

A further reason for doing so arises from the fact that small and poor countries have been seriously disadvantaged in the recent past in having to sign agreements that they have had limited ability to participate in or influence. One advantage to countries of knowing that adherence to all agreements is not obligatory is that it would relieve them of the burden that they are currently under to follow all aspects of the negotiations. This has proved to be extremely onerous especially for the smaller countries that have small delegations in Geneva, but that are nevertheless obliged to follow discussions on numerous and disparate subjects. The problem of limited negotiating capacity would thus be addressed to a considerable extent.

In recent discussions, a broad consensus seems to be emerging that such obligations should not be imposed on the small and poor countries. For example, it appears increasingly likely that the small and poor countries will not be required to take on any obligations with respect to the Singapore issues. 


\section{Limiting Welfare-Enhancing Obligations}

However, what about obligations, such as import liberalization or adherence to rules such as the prohibition of quantitative restrictions, that are welfare enhancing? In the Doha Round, developing countries are urging that less market access concessions be demanded of them both in goods and services. ${ }^{12}$ Some have even argued that the tightening of disciplines on protectionist measures in the Uruguay Round such as local content requirements and the use of quantitative restrictions for balance of payments reasons needs to be revisited.

Nevertheless, a thorny question arises in relation to obligations, such as tariff liberalization and adherence to rules prohibiting quantitative restrictions that are in principle welfareenhancing for these countries. Should such obligations be imposed on these countries even when they do not receive?

To be sure, welfare gains could accrue to these countries from curtailing their freedom to use quotas or impose higher protection. However, more fundamentally, unreciprocated trade liberalization in the WTO is and will be seen as an imposition much like conditionality under Fund and Bank programs. At a time, when the Bretton Woods Institutions themselves are moving away from top-down conditionality toward country ownership of economic reform programs, it would be anomalous for the WTO not to move in a similar direction-indeed developing country discontent in the WTO post-Uruguay Round is a consequence of not doing so.

Moreover, small and poor countries could still have the option of unilaterally taking on WTO obligations if they wished - for example as a means of signaling to markets their commitment to reforms - but there need be no requirement to do so. ${ }^{13}$

Larger countries do not find it difficult to consent to relieving these countries of such obligations because in political economy terms it does not cost them very much. As we illustrated earlier, industrial countries have revealed an indifference to market opening commitments by smaller countries: the foregone exports are simply too small.

\section{E. Financial Compensation}

In principle, accommodating the concerns of the small and poor countries through the provision of financial and technical assistance is highly desirable. It also enlarges the space over which mutually beneficial deals can be struck in the WTO. From the perspective of the

\footnotetext{
${ }^{12}$ See developing country submissions leading up to the Doha and Cancun ministerials.

${ }^{13}$ Of course, the value to small and poor countries of adhering to WTO obligations even as a signal might be limited if partners have little incentive to enforce the obligations as we suspect.
} 
larger countries, offers of incremental aid may be more feasible than offers of unreciprocated market access. The reason resides in the different political economy of aid and trade. The political pain of increasing aid is likely to be diffuse, widely spread over millions of taxpayers, reducing the resistance to it. Offers of additional market access, on the other hand, would involve inflicting losses on a small group of import-competing producers, who are likely to offer stiff resistance, making it politically difficult for the government to sustain any unreciprocated market access concessions.

However, four major challenges present themselves. First, will any offer of financial assistance be truly additional to what small and poor countries would otherwise get? Second, can these offers be credible and binding? The stalemate at Cancun reflected in part developing countries' perception that previous commitments to financial assistance had not been met. Third, is there enough coordination between trade and aid/finance agencies within countries that would allow such offers to be rendered credible. The much-talked about issue of coherence in the international architecture between the WTO, IMF, and the World Bank has to be underpinned by coherence within countries between different agencies of government (see also Hoekman and others 2003). Can the hydra-headed monster of government act consistently in a way that allows trade and finance decisions to be made coherently? And finally will the additional aid be used productively to enhance long-term development? This question is especially relevant in light of the evidence casting doubts about the effectiveness of development assistance more broadly (Easterly, 2003).

However, unlike the WTO bargain of mutual exchange of market access concessions, the aid-for-liberalization bargain runs into political economy problems at the recipient country's end. Improved market access creates a group of winners (exporting industries) that have concentrated interests and can help countervail the resistance from import-competing interests. In the case of aid, the direct beneficiary is usually the government, rather than any concentrated domestic constituency that can help offset the resistance from import-competing industries. However, if trade restrictions are predominantly a fiscal instrument or a source of corruption, the trade-for-aid bargain may be effective. In this case, the losers from trade liberalization would be the government and bureaucrats who might see additional aid as compensation for foregone fiscal revenues and rents from corruption.

\section{F. Putting the Options Together}

The analysis of the options suggests that political economy considerations (which determine the feasibility of the different options) are making the system gravitate toward three of the five options discussed above: granting further preferential access to the small and poor countries; relieving them of financially costly and welfare-deteriorating obligations; and even relieving them of obligations that may be in the interests of these countries.

This is unfortunate because clearly the more desirable way of accommodating the small and poor countries is to provide them with further financial and technical assistance and with further nonpreferential access options in return for their consenting to the system moving forward with the broader liberalization agenda, as well as a quid pro quo for their own liberalization efforts. 
Thus, the stark reality is that desirable outcomes are infeasible and feasible ones are less desirable.

\section{Concluding Remarks}

The WTO faces a challenge when it comes to the situation of the small and poor countries. This challenge has arisen because of the conjunction of three elements. On the one hand, because of the Uruguay Round's Single Undertaking, small and poor countries have acquired a significant say and legal influence in WTO decision-making. On the other hand, because of their size, they have limited ability to engage in the reciprocity game that is at the heart of the WTO and the manner in which it operates. In addition, their interests are only imperfectly aligned with those of the system.

If the concerns of the small and poor countries could be addressed, then it would be easier for the WTO to focus on the important task of eliminating barriers to goods, services, and factor flows between industrial and large developing countries. With the scope for mutually beneficial bargains between industrial countries shrinking, the real action in the WTO over the next few decades would be bargains between industrial and the larger developing countries. These countries have relatively closed markets for services, capital, and manufacturing which would serve as their bargaining chips. On the other side, industrial countries have closed markets for clothing, agriculture, and labor-intensive services. It is over this bargaining space that the next big push for globalization could be facilitated by the WTO.

However, how is the multilateral trading system to accommodate the interests of the small and poor countries? This is desirable in itself but is also necessary to ensure smooth and expeditious progress in the Doha Round, especially in an intellectual and political climate that is so geared to ensuring a fair outcome for these countries.

Unfortunately, the desirable ways of accommodating the interests of small and poor countries are proving infeasible. As a result, the system is gravitating toward the less desirable but feasible options. The preferred course of action would involve providing small and poor countries compensation in the form of improved nonpreferential access and increased financial and technical assistance, in return for their consenting to the system moving forward with the broader liberalization agenda, as well as a quid pro quo for their own liberalization efforts. However, there are significant political economy problems both at donor and recipient end that render the provision of aid and market access difficult.

The system is moving toward options that involve providing further nonpreferential access, relieving small and poor countries of financially costly and welfare-diminishing obligations such as the Customs Valuation and TRIPs agreements but also other market liberalization obligations that are welfare enhancing for them. In some ways, this move is unsurprising as it involves a reversion to the two-tier system that prevailed prior to the Uruguay Round, albeit with changed actors: the second tier being occupied by today's small and poor countries just as it was occupied pre-Uruguay Round by the then poor and small countries. 


\section{References}

Anderson, K., B. Dimaranan, J. Francois, T. Hertel, B. Hoekman, and W. Martín, 2002, "The Cost of Rich (and Poor) Country Protection to Developing Countries," Journal of African Economies, Vol. 10, No.3 pp. 227-57.

Bhagwati, Jagdish, 2004, In Defense of Globalization (New York: Oxford University Press).

Chaudhri, S., P.K. Goldberg, and P. Jia, 2003, “The Effects of Extending Intellectual Property Rights Protection to Developing Countries: A Case Study of the Indian Pharmaceutical Market," NBER Working Paper No. 10159 (Cambridge, Massachusetts: National Bureau of Economic Research).

Cline, W., 2004, Trade Policy and Global Poverty, (Washington: Institute for International Economics), forthcoming.

Easterly, W., 2003, “Can Foreign Aid Buy Growth?” Journal of Economic Perspectives, Vol. 17, No. 3, pp. 23-48.

Finger, J.M. 2002, The Doha Agenda and Development: A View From the Uruguay Round, (Manila: Asian Development Bank).

Finger, J.M. and P. Schuler, 2000, "Implementation of Uruguay Round Commitments: The Development Challenge," The World Economy, Vol. 23, pp. 511-26.

Hoekman, B., C. Michalopoulos, and L.A. Winters, 2004, "Special and Differential Treatment of Developing Countries in the WTO: Moving Forward After Cancún," The World Economy.

Hoekman, B., F. Ng, and M. Olarreaga, 2002a, "Eliminating Excessive Tariffs on Exports of Least Developed Countries," World Bank Economic Review, Vol. 16, No. 1, pp. 1-21.

2002b, “Agricultural Tariffs versus Subsidies: What's More Important for Developing Countries," forthcoming, World Bank Economic Review.

Ianchovicina, Elena, Aaditya Mattoo and Marcelo Olarreaga, 2002, "Unrestricted Market Access for Sub-Saharan Africa: How Much Is It Worth and Who Pays?," Journal of African Economies, Vol. 10, No. 4, pp. 410-32.

Mattoo, A., D. Roy, and A. Subramanian, 2003, "The Africa Growth and Opportunity Act and its Rules of Origin: Generosity Undermined?," The World Economy, Vol. 26, No. 6, pp. 829-51.

Martin, W., and D. Tarr, 2001, "Liberalizing Agriculture and Manufactures," The World Economy, Vol. 23, No. 4, pp. 455-70. 
Messerlin, P., 2003, "Making the Doha Development Round Work for the Poorest Developing Countries," in Rethinking Fair Trade, ed. by P. Griffith (London: The Foreign Policy Centre).

Olarreaga, Marcelo and Caglar Ozden, "AGOA and Apparel: Who Captures the Tariff Rent in the Presence of Preferential Market Access?," World Economy, forthcoming.

Ozden, C., and E. Reinhardt, 2003, "The Perversity of Preferences: The Generalized System of Preferences and Developing Country Trade Policies," World Bank Policy Research Working Paper No. 2955, (Washington: World Bank).

Panagariya, A., 2003, “Your Move, Mr. Jaitley!,” Op-ed, Economic Times, February 26.

Romalis, J., 2003, “Would Rich Country Trade Preferences Help Poor Countries Grow? Evidence from the Generalized System of Preferences," (unpublished; Chicago: Graduate School of Business, University of Chicago).

Subramanian, A., and Shang-Jin Wei, "The WTO Promotes Trade, Strongly But Unevenly," 2003, NBER Working Paper No. 10024 (Cambridge, Massachusetts: National Bureau of Economic Research).

Tokarick, S., 2003, "Measuring the Impact of Distortions in Agricultural Trade in Partial and General Equilibrium," IMF Working Paper 03/110 (Washington: International Monetary Fund).

Wolf, M., 2003, “The Abominable No-Men,” Financial Times Column, September 23.

World Bank, 2003, Global Economic Prospects 2004: Realizing the Development Promise of the Doha Agenda, (Washington: World Bank). 